\title{
Modelling coupled hydraulics and sediment transport of a high-magnitude flood and associated landscape change
}

\author{
Jonathan L. CARRIVICK \\ School of Geography, University of Leeds, West Yorkshire LS2 9JT, UK \\ E-mail: j.l.carrivick@leeds.ac.uk
}

\begin{abstract}
Processes and mechanisms of erosion, transport and deposition within high-magnitude outburst floods such as jökulhlaups and lahars are poorly understood and remain largely unquantified. This study therefore applies a two-dimensional or depth-averaged hydrodynamic model, with fully integrated sediment transport, to reconstruct a Holocene jökulhlaup to have occurred from Kverkfjöll volcano, Iceland. Results indicate simultaneous inundation of multiple channels, flow around islands, hydraulic jumps and multi-directional flow including backwater areas and hydraulic ponding. These flow characteristics are typical of outburst floods that are volcanically triggered, flow through steep volcanic terrain and contain high concentrations of volcaniclastic sediment. Kverkfjöll jökulhlaups had low frontal flow velocities but as stage increased, velocities reached $5-15 \mathrm{~m} \mathrm{~s}^{-1}$. Peak stage was prolonged in zones of hydraulic ponding, but generally attenuated in magnitude and duration downstream. Suspended load transport persisted over the entire hydrograph but bed load transport was spatially discontinuous and comprised distinct pulses. A hierarchy of landforms is proposed, ranging from highest energy zones (erosional gorges, scoured bedrock, cataracts and spillways) to lowest (valleyfills, bars and slackwater deposits). Bedrock erosion was generally where flow exceeded $\sim 3 \mathrm{~m}$ flow depth, $\sim 7 \mathrm{~m} \mathrm{~s}^{-1}$ flow velocity, $\sim 1 \times 10^{2} \mathrm{~N} \mathrm{~m}^{-2}$ shear stress and $3 \times 10^{2} \mathrm{~W} \mathrm{~m}^{-2}$ stream power. Deposition occurred below $\sim 8 \mathrm{~m}$ flow depth, $11 \mathrm{~m} \mathrm{~s}^{-1}$ flow velocity, $5 \times 10^{2} \mathrm{~N} \mathrm{~m}^{-2}$ shear stress and $3 \times 10^{3} \mathrm{~W} \mathrm{~m}^{-2}$ stream power. Hydraulic ranges associated with erosion and deposition have considerable overlap due to transitional flow phenomena, transitions in sediment concentration and the influence of upstream effects, such as hydraulic ponding behind topographic constrictions. These results are the first of coupled hydraulic and sediment transport phenomena in high-magnitude outburst floods with fluid rheology and high sediment content, such as jökulhlaups and dilute lahars. Modelled changes in sediment mass closely resembled field-mapped zones of erosion and deposition. This paper therefore introduces a capability to simulate rapid landscape change due to high-magnitude outburst flood.
\end{abstract}

\section{AIMS, INTRODUCTION AND RATIONALE}

The aims of this paper are firstly to calculate transient hydraulics and sediment transport within a subaerial highmagnitude outburst flood. This paper will specifically focus on a bedrock-channelled jökulhlaup. The importance of accounting for downstream attenuation of peak discharge and of including sediment transport and bed mobility or flow-bed interactions will be emphasized. Neither of these properties has previously been addressed in jökulhlaup flow propagation models. Secondly, this paper will examine the association of modelled hydraulics with landforms and sediments produced by that jökulhlaup, as it is these landforms and sediments that have previously been used to infer flow conditions.

Subaerial high-magnitude outburst floods are a sudden release of water and sediment with discharges that are several orders of magnitude greater than perennial flows (Costa, 1988; Costa and Schuster, 1988; Clague and Evans, 2000). Two common types of subaerial high-magnitude flood are jökulhlaups and lahars. The former are outburst floods associated with a glacial source, and the latter are outburst floods that specifically comprise volcaniclastic sediment. With coincidence of glaciers and volcanoes, jökulhlaups and lahars become indistinct from each other, since both comprise glacially derived meltwater and volcaniclastic sediment. However, on the basis of sediment concentration, the term jökulhlaup typically becomes reserved for fluid flows and the term lahar for mass slurry flows or granular flows. This terminology rather simplifies these high-magnitude flood phenomena, as sediment concentrations are highly transient within a single event. For example, jökulhlaups have been noted to become progressively more fluidal as initially voluminous sediment supply is exhausted (e.g. Marcus, 1989; Maizels, 1993; Russell and Marren, 1999; Carrivick and others, 2004b) and some jökulhlaups involve sediment volumes much greater than the transporting water volume (Lliboutry and others, 1977; Haeberli, 1983). Initially fluid lahars can become bulked by rapid sediment entrainment (Cronin and others, 1997; Scott and others, 2001; Lavigne and Thouret, 2003).

Jökulhlaups and lahars are far too sudden, powerful, remote and short-lived for direct measurements of flow characteristics. Consequently, jökulhlaup landforms and sediments have been described, interpreted and classified, thereby developing qualitative conceptual models of jökulhlaup flow dynamics, flow rheology and the control of jökulhlaup magnitude and frequency on proglacial geomorphology and sedimentology (Maizels and Russell, 1992; Maizels, 1993; Maizels, 1997; Rushmer and others, 2002; Marren, 2005; Rushmer, 2006; Russell and others, 2006). Landforms and sediments of lahars have tended to focus upon site-specific determinations of flood run-out extent, flow volumes and sedimentological inferences of rheology 


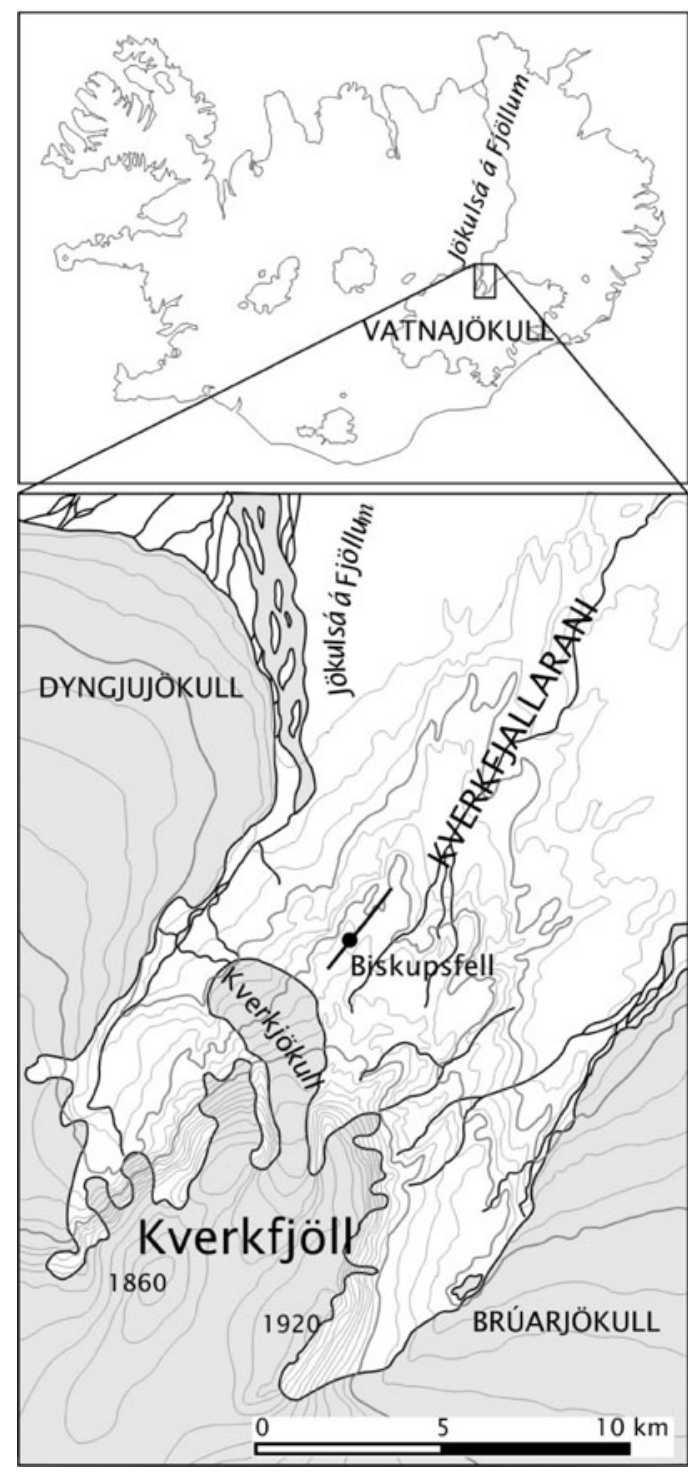

Fig. 1. Kverkfjöll is located on the northern margin of Vatnajökull, Iceland. Kverkfjallarani is the northern and proglacial area of the Kverkfjöll Volcanic System (KVS).

(e.g. Lavigne and Thouret, 2003; Capra and others, 2004; Manville and White, 2004). Lahar reconstructions from landforms and sediments have primarily been motivated to produce frontal advance timings (e.g. Fagents and Baloga, 2005), and magnitude-frequency regimes (e.g. Bursik and Reid, 2004; Jakob and others, 2005) for hazard planning.

\section{STUDY SITE}

Hydraulic reconstructions are made of the largest jökulhlaup to have originated from Kverkfjöll during the Holocene (Carrivick, 2005). Kverkfjöll is a glaciated stratovolcano on the northern margin of Vatnajökull (Jóhannesson and Saemundsson, 1989) (Fig. 1). This study site is chosen because Kverkfjallarani (Fig. 1), the northern and proglacial area of the Kverkfjöll Volcanic System (KVS), contains comprehensive field evidence of a high-magnitude jökulhlaup (Carrivick and others, 2004a, b; Carrivick, 2005). Additionally, a high-resolution Digital Elevation Model (DEM) - a $10 \mathrm{~m}$ horizontal grid with sub-metre vertical accuracy - of Kverkfjallarani exists (Carrivick and Twigg,
2005), essential for input to hydrodynamic models for the purpose of geomorphological analyses.

Kverkfjallarani is bounded to the east by the margin of Brúarjökull and the Kreppa river and to the west by Dyngjujökull and the Jökulsá á Fjöllum river (Fig. 1). Kverkfjallarani is dominated by a series of parallel volcanic pillow hyaloclastite ridges, each typically $100 \mathrm{~m}$ high and several kilometres long (Hannesson, 1953; Jóhannesson and Sæmundsson, 1989). Holocene jökulhlaups through Kverkfjallarani were bound by these ridges (Carrivick and others, 2004a). Each ridge marks a fissure that erupted beneath the Weichselian ice sheet (Karhunen, 1988; Höskuldsson and others, 2006), is heavily weathered and typically supports pillow lava bricks in scree slopes at angles of $30-40^{\circ}$ (Hannesson, 1953) and up to $45^{\circ}$ (Beckett, 1934). Pillow lava bricks result from weathering along radial fractures and are a major sediment source to Kverkfjallarani jökulhlaups (Carrivick and others, 2004b). Kverkfjallarani also contains extensive subaerial lava flows and crater rows. Lava flows are basaltic and fill valley floors between ridges (Beckett, 1934; Karhunen, 1988). Both lava flows and crater rows, which are up to $8 \mathrm{~km}$ long (Karhunen, 1988), indicate that eruptions have occurred within Kverkfjallarani during the Holocene, mostly (but not exclusively) from the Biskupsfell fissure. Subaerial lava flows are a source of massive 1-2 m blocks to Kverkfjallarani jökulhlaups (Carrivick and others, 2004b).

\section{METHOD}

Quantitative models of jökulhlaups and other large floods utilize engineering fluid dynamics programs. The most widely used of these are the one-dimensional Hydraulic Engineering Centre HEC-2 and its successor HEC-RAS, particularly the latter as it has a graphical user interface and is GIS-based. With increases in computational power, two-dimensional depth-averaged numerical models have been used to reconstruct both unconfined Iceland jökulhlaup flows (Eskilsson and others, 2002) and confined Missoula flows (Denlinger and O'Connell, 2003). These models use a source hydrograph to initiate the cellular routing of floodwater over a DEM. Two-dimensional modelling therefore offers greater resolution for studies of transient hydrodynamics and rapid landscape change due to highmagnitude outburst floods such as jökulhlaups. Hydraulic calculations independent of landforms preserved within flood routeways can be completed, allowing both spatial and temporal variations of hydraulics to be considered. Carrivick and Rushmer (2006) provide a succinct review of both qualitative and quantitative palaeohydraulic methods.

Quantitative lahar modelling has been much more limited than for jökulhlaups, as physical equations of debris flows and sediment-laden flows rely on scaled flume experiments and particle debris flow theory (e.g. Major, 2000; Denlinger and Iverson, 2001; Iverson and Denlinger, 2001; Iverson and Vallance, 2001). Consequently, quantitative lahar modelling has been primarily interested in runout extent (e.g. Canuti and others, 2002; Stevens and others, 2003). Iverson and others (1998) used scaling and statistical analyses of 27 lahar paths at 9 volcanoes to predict inundated valley sections and areas as functions of the lahar volume.

The model used in this paper is Delft3D, from WI DelftHydraulics (http://www.wldelft.nl/soft/d3d/intro/). Delft3D is a graphically interfaced hydrodynamic model that routes a user-specified hydrograph over an orthogonal grid (Fig. 2). 


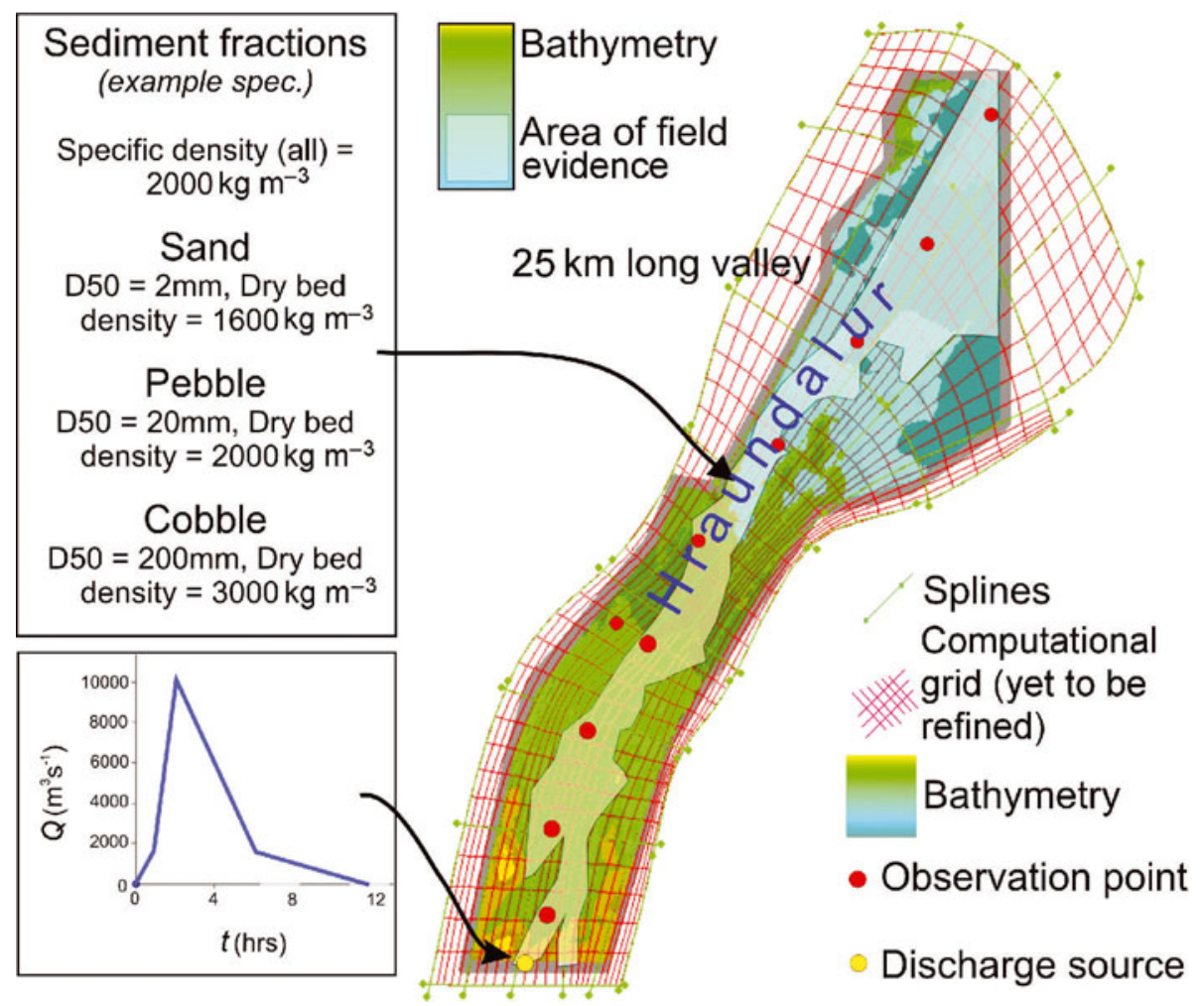

Fig. 2. Diagram of model input, illustrating bathymetric depth derived from a Digital Elevation Model (DEM) and computational orthogonal grid with a shape specified by user-defined splines. Flood input hydrograph and typical sediment fractions are also given. Sediment can be input with the hydrograph and pre-exist along the channel. Area of field evidence is after Carrivick and others (2004a).

Grid nodes specify bathymetric depth points and surface attributes such as roughness and sediment character. The orthogonal grid is defined by manually describing splines, which then become converted to a grid that is then refined in the $x$ and $y$ directions to a desired resolution (Fig. 2). An orthogonal grid therefore permits areas of interest to be modelled at high spatial resolution $(1 \mathrm{~m})$ and other areas to be modelled coarsely (10-100 m grid node spacing). Bathymetric depth points were processed from the DEM of Carrivick and Twigg (2005) and surface attributes were obtained from extensive field measurements (Carrivick, 2005). Delft3D is used because it is numerically stable for conditions of unsteady flows (including steep terrain), kinematic waves, wetting and drying and because it couples sediment transport with hydrodynamics. The full St-Venant hydrodynamic equations, as used by the model, are described by Sleigh and Goodwill (2000). Bed load transport is modelled using the equations of Meyer-Peter and Müller (1948) and suspended transport according to Van Rijn (1984). Sediment transport is modelled for clasts up to $200 \mathrm{~mm}$ diameter, which is an order of magnitude greater than for which the Meyer-Peter and Müller (1948) equations were derived. Clasts greater than $200 \mathrm{~mm}$ and of up to $2000 \mathrm{~mm}$ diameter as observed in the field (Carrivick and others, 2004a, b) are therefore not modelled. The hydrograph used in this study (Fig. 2) is fully explained by Carrivick (2005) and is reconstructed from field evidence of water surface elevations that, through slope-area calculations, suggest a peak discharge of $\sim 100000 \mathrm{~m}^{3} \mathrm{~s}^{-1}$. The magnitude of this peak discharge implies a water volume in excess of the volume of a Kverkfjöll caldera, if conduit expansion by melting is assumed using the Clague-Matthews (1973) relationship (Carrivick, 2005, 2006). However, this peak discharge estimate can be accounted for if a volcanic trigger is invoked (Carrivick, 2005, 2006). The jökulhlaup reconstructed in this paper is therefore assumed to have a 'rapid rise to peak' shape. For model runs in this paper, sediment was not input to the system but was specified to be preexisting with a uniform depth of $20 \mathrm{~m}$ split into size fractions (Fig. 2). Sediment depths and size fractions are as recorded by Carrivick and others (2004a, b).

The model calculates incremental grids or 'maps' of flow depth, flow velocity and the net gain/loss of sediment within each grid cell. It is noted for clarification that the Delft3D model is a coupled hydraulic sediment transport model and computes mass changes in pre-existing sediment per grid cell. Feedbacks between sediment entrainment and flow hydraulics are therefore accounted for, although bed elevation change at each grid node was not computed in these model runs. Furthermore, the grid geometry does not change. It should also be noted that bathymetry, or bed elevation, is derived from post-flood topographic surveys. Specific points of interest are recorded at observation stations (Fig. 2) where hydraulic and sediment parameters are written to file. Furthermore, all results presented in this paper are from a single layer grid. They are therefore twodimensional or depth-averaged models runs.

Mapping and interpretation of jökulhlaup impacts and hence of flow routeways through Kverkfjallarani was initially made from 1:30000 aerial photographs. Extensive fieldwork was undertaken during the summers of 2000-2002 and comprised topographic surveys of palaeochannel (valley) cross-sections and field mapping of subaerial lava flows and jökulhlaup landforms. Remotely sensed and field data therefore characterized geomorphology, identified jökulhlaup routeways and interpreted characteristics of 


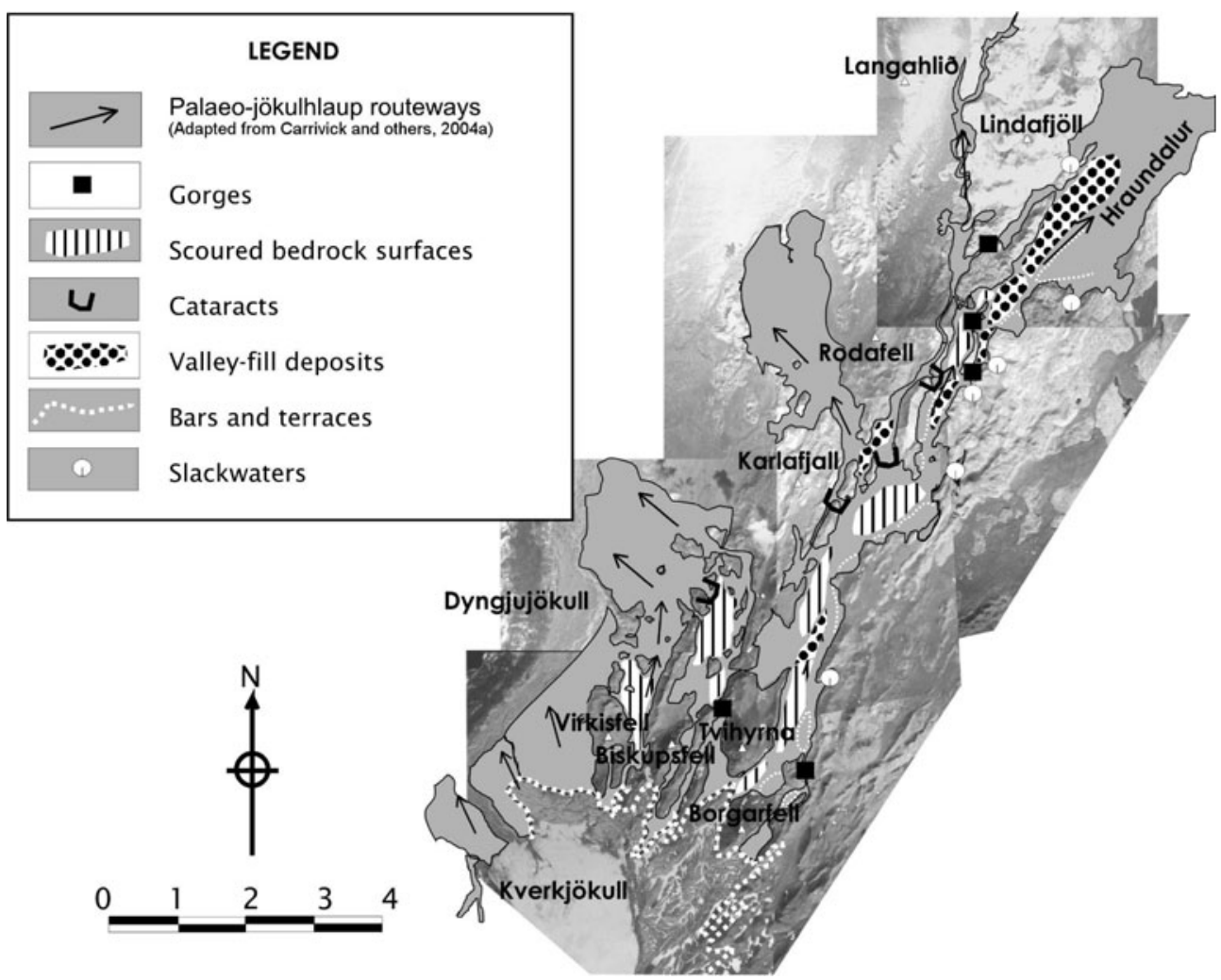

Fig. 3. Field-mapped landforms attributed to high-magnitude outburst floods in Kverkfjallarani.

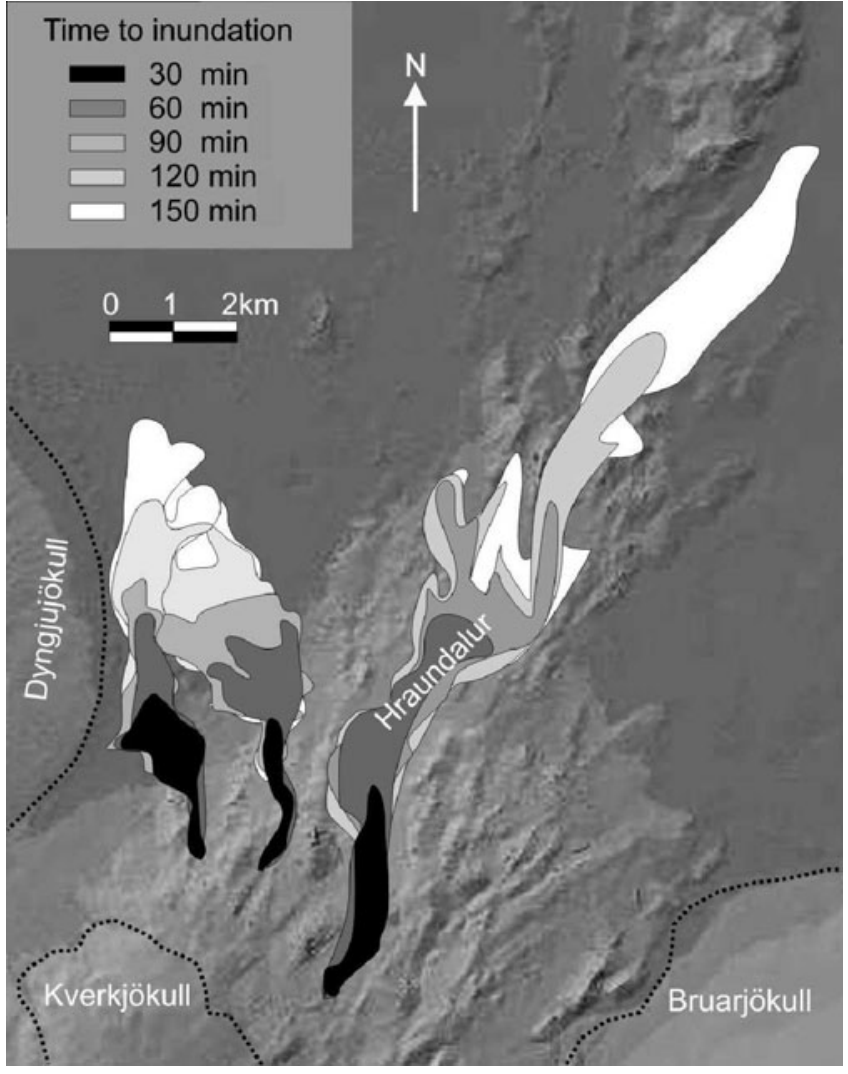

Fig. 4. Schematic illustration of the time to inundation by glacial outburst floods (jökulhlaups) from Kverkfjöll of the Kverkfjallarani bedrock landscape. The main northeast-trending valley is Hraundalur. Floods routing northwest were of a lower discharge and of slower frontal velocity than the Hraundalur example. those jökulhlaups from this evidence. A set of criteria was developed to distinguish landforms that are the product of bedrock-channelled jökulhlaups from landforms that are the products of other processes (Carrivick and others, 2004a).

In order to analyze geomorphic work or flow hydraulics associated with different landforms, 53 separate landforms and different sedimentary surfaces within Kverkfjallarani jökulhlaup routeways (Fig. 3) were mapped into a GIS. Between 5 and 10 examples of each landform type were identified and analyzed (Fig. 3). Hydraulic maps were output from the model at regular time stages after flood initiation and also for maximum, minimum and mean hydraulics per grid cell. These hydraulic maps were also imported into the GIS and hence hydraulics described for each landform group.

\section{RESULTS}

Geomorphological and sedimentological evidence of jökulhlaups from Kverkfjöll has been described in detail by Carrivick and others (2004a, b respectively) and peak flow hydraulics have been reconstructed by means of palaeocompetence and slope-area reconstructions (Carrivick, 2005, 2006). Hydrodynamic reconstructions in this paper will therefore emphasize spatial and temporal variations in hydraulics and sediment transport.

\section{Spatial and temporal variation in jökulhlaup hydraulics and sediment transport}

The $25 \mathrm{~km}$ long Hraundalur valley became inundated within $\sim 3$ hours (Fig. 4). Mean frontal velocity was $\sim 2.3 \mathrm{~m} \mathrm{~s}^{-1}$, although this varied with a much slower frontal velocity upslope of the major channel construction. Since channel geometry is fixed, water stage is a proxy for discharge, and 


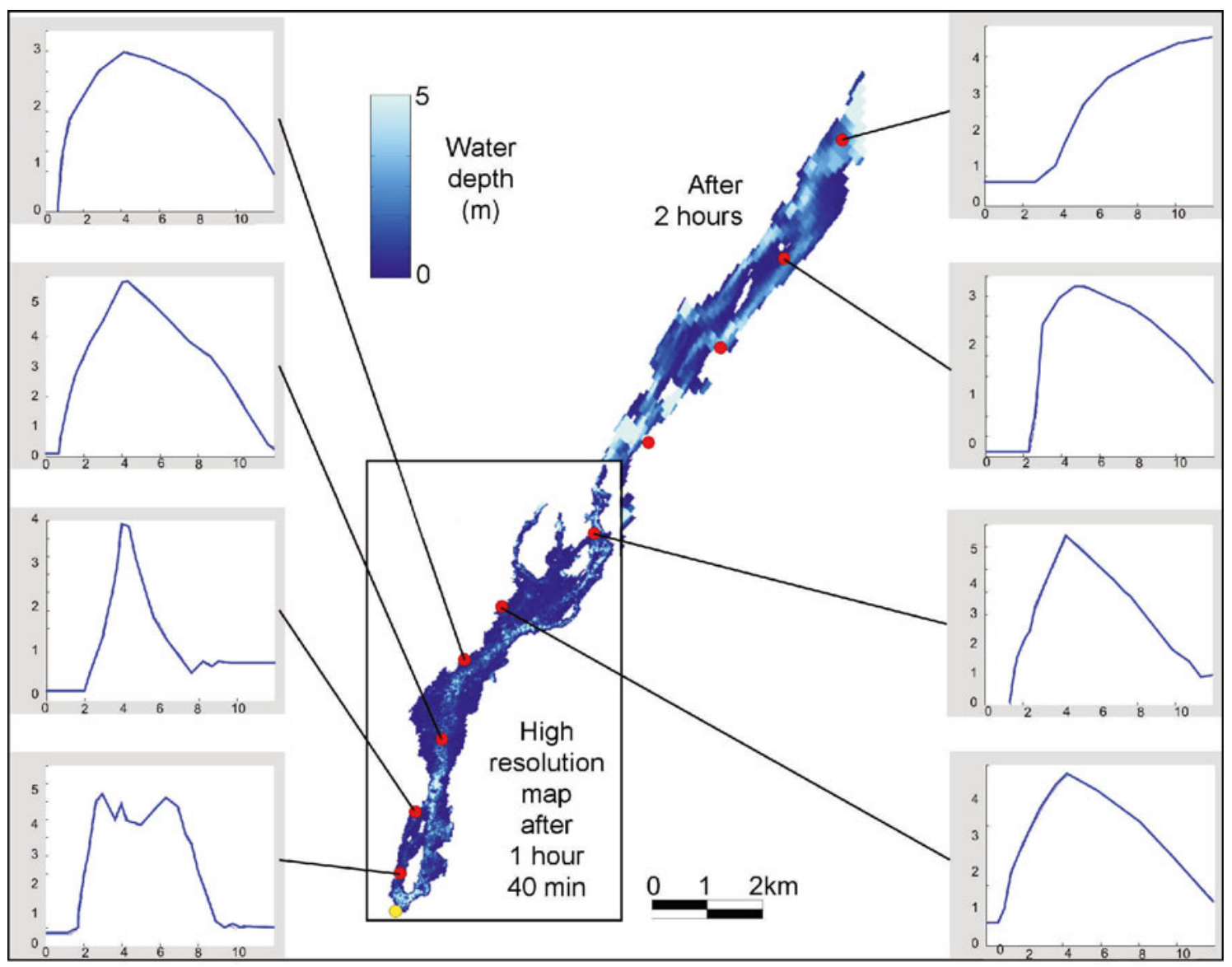

Fig. 5. Spatial and temporal variation in relative water depth $(\mathrm{m})$ of a $100000 \mathrm{~m}^{3} \mathrm{~s}^{-1}$ jökulhlaup routing along Hraundalur, Kverkfjallarani. Note prolonged peak stage in areas of hydraulic ponding, and general downstream attenuation. This model run considers $100 \%$ water flow. $x$ scale is time (hours) since flood initiation. Note $y$ scale $(\mathrm{m})$ varies between graphs.

this attenuated very rapidly downstream (Fig. 5). It is interesting to note that the rate of rise to peak stage is generally consistent between sites and coincident with the timing of peak discharge (Fig. 2), but that the magnitude of peak stage and subsequent stage recession rates vary considerably (Fig. 5). Peak stage magnitude generally decreases and peak stage duration generally increases with distance downstream. However, a few exceptions occur where hydraulic ponding causes a prolonged peak stage and in zones of narrow channel width where the hydrograph becomes very flashy (Fig. 5).

At peak stage (after 2 hours), supercritical flow predominated in proximal reaches, was intermittent in medial reaches, and generally absent from distal reaches (Fig. 6a). On the rising stage, after 1.5 hours, a number of highmagnitude flow phenomena can be described. These include: mid-valley islands causing flow acceleration and a meandering thalweg (Fig. 6b); temporary hydraulic ponding where flow spills over low divides between midchannel islands and where valley constrictions dramatically reduce channel widths (Fig. 6c); and very steep water surface gradients between flow depths upstream of a severe construction that are up to an order of magnitude greater than flow depths immediately downstream (Fig. 6c). Inundation of tributary valleys and other backwater sites therefore largely depends on flow depth. The rapidly varied nature of flow conditions is further illustrated by the contrast between over-bank and backwater flow shear stress (Fig. 6d).
Sediment transport comprised suspended load and bed load, and is discriminated by the calibre of material entrained at a given shear stress. Suspended load, which in the Hraundalur jökulhlaup comprised volcaniclastic scoria, spatter, pumice, tuff fragments and pillow lava blocks (Carrivick and others, 2004b), persists over the duration of the flood hydrograph within both relatively deep and shallow flows (Fig. 7). While suspended load transport was sustained in the upper reaches of Hraundalur, it became discontinuous in the lower reaches due to a dissipation of flow energy. In contrast, bed load transport was highly variable in space and time and occurred only in the relatively deep main channel (Fig. 7). Additionally, bed load transport featured pulses and become rapidly exhausted after peak discharge. Net sediment gain and loss per grid cell was modelled as a mass change and infers erosion or deposition. Note that bed elevation change was not modelled. Mass changes in sediment were predominantly negative, i.e. erosional, except for within hydraulically ponded zones and marginal embayments (Fig. 8). Some mid-channel deposition occurred immediately downstream of islands (Fig. 8).

\section{Association of modelled hydraulics with field-mapped landforms and sediments}

Ranges of hydraulic parameters can be defined for each landform type, in a manner similar to that presented by O'Connor (1993) and Benito and O'Connor (2003) for the Bonneville and Missoula megafloods, for example. Figure 9 clearly show that erosional landforms are associated with 


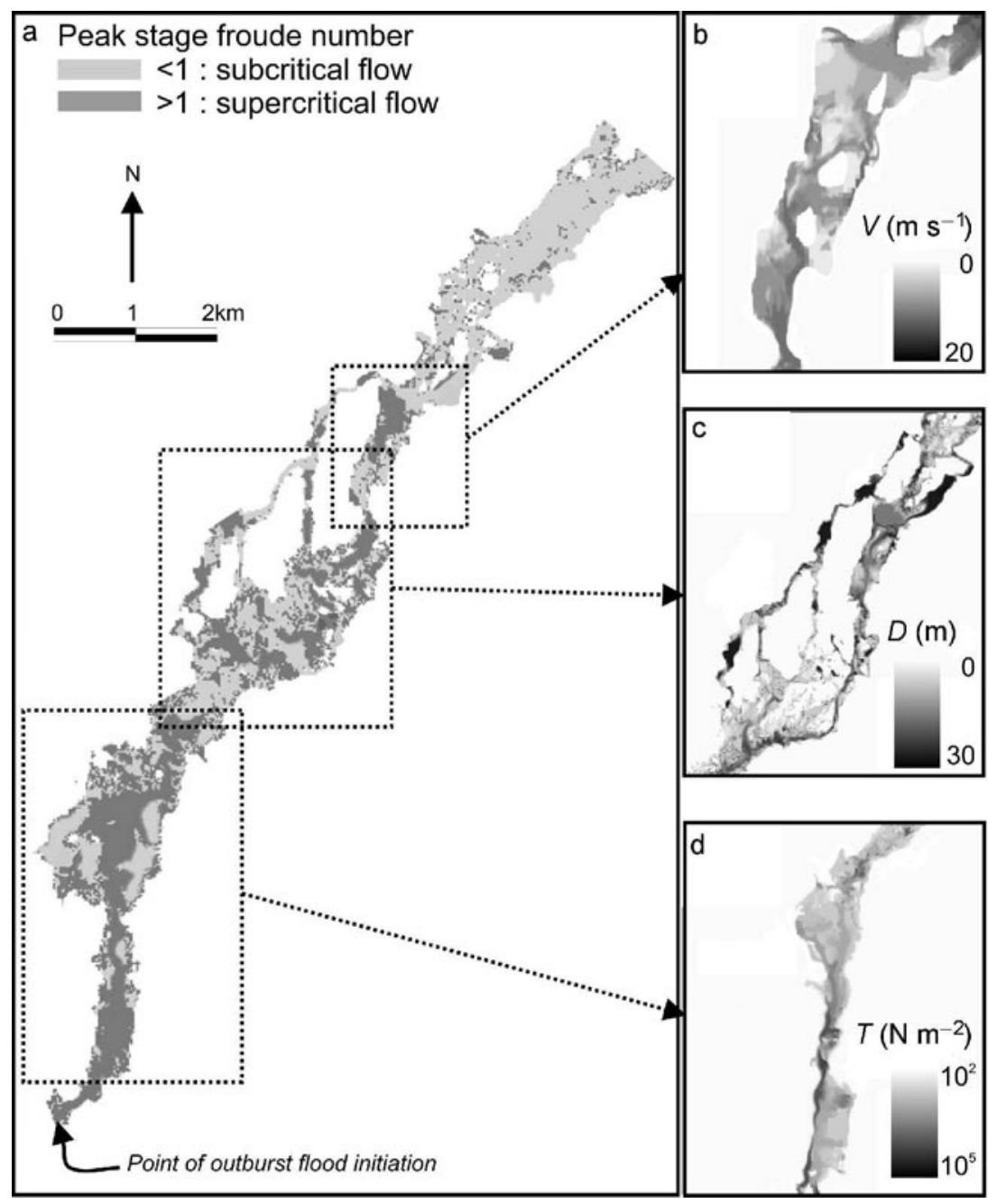

Fig. 6. Examples of 2D hydrodynamic model output and GIS-based calculations of (a) flow regime at peak stage after 2 hours, (b) flow velocity after $1 \mathrm{hr} 30 \mathrm{~min}$, (c) flow depth at peak stage and (d) shear stress after 1 hour. Note that diagrams do not necessarily pertain to the same model run, nor to the same hydrograph stage.

much higher flow depths, flow velocities, shear stresses and stream powers than depositional landforms. These ranges define both maximum and minimum thresholds of hydraulic parameters within which landform types are located. It is clear that there is no unique range of hydraulics associated with particular landform type, i.e. many of the ranges overlap (Fig. 9). Indeed, depositional and erosional ranges also overlap. This is because of the transient nature of hydraulic parameters, particularly due to turbulence and the development of spatially discordant supercritical flow.

Landform group hydraulics allows a quantitative hierarchy of landforms to be proposed. This hierarchy is ordered from landforms situated in zones of deep, fast and high-energy flow to landforms situated in shallow, slow and low-energy flow. Gorges are at the top of this hierarchy and are characterized by mean shear stresses and stream powers of $100-3400 \mathrm{~N} \mathrm{~m}^{-2}$ and $3500-20000 \mathrm{~W} \mathrm{~m}^{-2}$ respectively (Fig. 9). Scoured bedrock surfaces extend over a far greater spatial area than gorges, which of course are linear features, but exhibit rather more stable flows as illustrated by smaller ranges and lower standard deviations of depths, velocities, shear stresses and stream powers (Fig. 9). Stream powers associated with scoured bedrock surfaces are 300$18500 \mathrm{~W} \mathrm{~m}^{-2}$, and thus approach maximum values associated with gorges. Cataracts occur where hydraulic conditions are similar though less varied in comparison to scoured bedrock surfaces. This is because cataracts are localized down-cuts into bedrock, and therefore flow will always be accelerating through these zones. Consequently, flow depths within cataract zones range from just $4.0-7.5 \mathrm{~m}$ over cataracts in comparison to $3-11.3 \mathrm{~m}$ on scoured bedrock (Fig. 9). A further factor to explain the range of flow depths associated with scoured bedrock zones is that some probably experience hydraulic ponding. Spillways, which are not show in Figure 9, are similar to cataracts but overtop topographic divides. Flow depths and velocities have low variance within spillway zones, with mean values varying from $5 \mathrm{~m}$ and $10 \mathrm{~m} \mathrm{~s}^{-1}$, respectively. Shear stresses and stream powers associated with spillways are low, with mean values of $200-500 \mathrm{~N} \mathrm{~m}^{-2}$ and $310-830 \mathrm{~W} \mathrm{~m}^{-2}$ respectively. Channel reaches with valley-fill deposits are associated with a range of flow depths that are similar to those of scoured bedrock zones. This is again attributed to the fact that valley-fill surfaces occur within the main channel and are therefore subjected to main flow hydraulics, which include both rising and falling stages of a flood hydrograph. However, in contrast to scoured bedrock reaches, valley-fill zones are located in reaches of shallow gradient. They have flow velocities of 6-11 $\mathrm{m} \mathrm{s}^{-1}$, which are much less and of a tighter range than the flow velocities of $7-16 \mathrm{~m} \mathrm{~s}^{-1}$ of scoured bedrock zones 

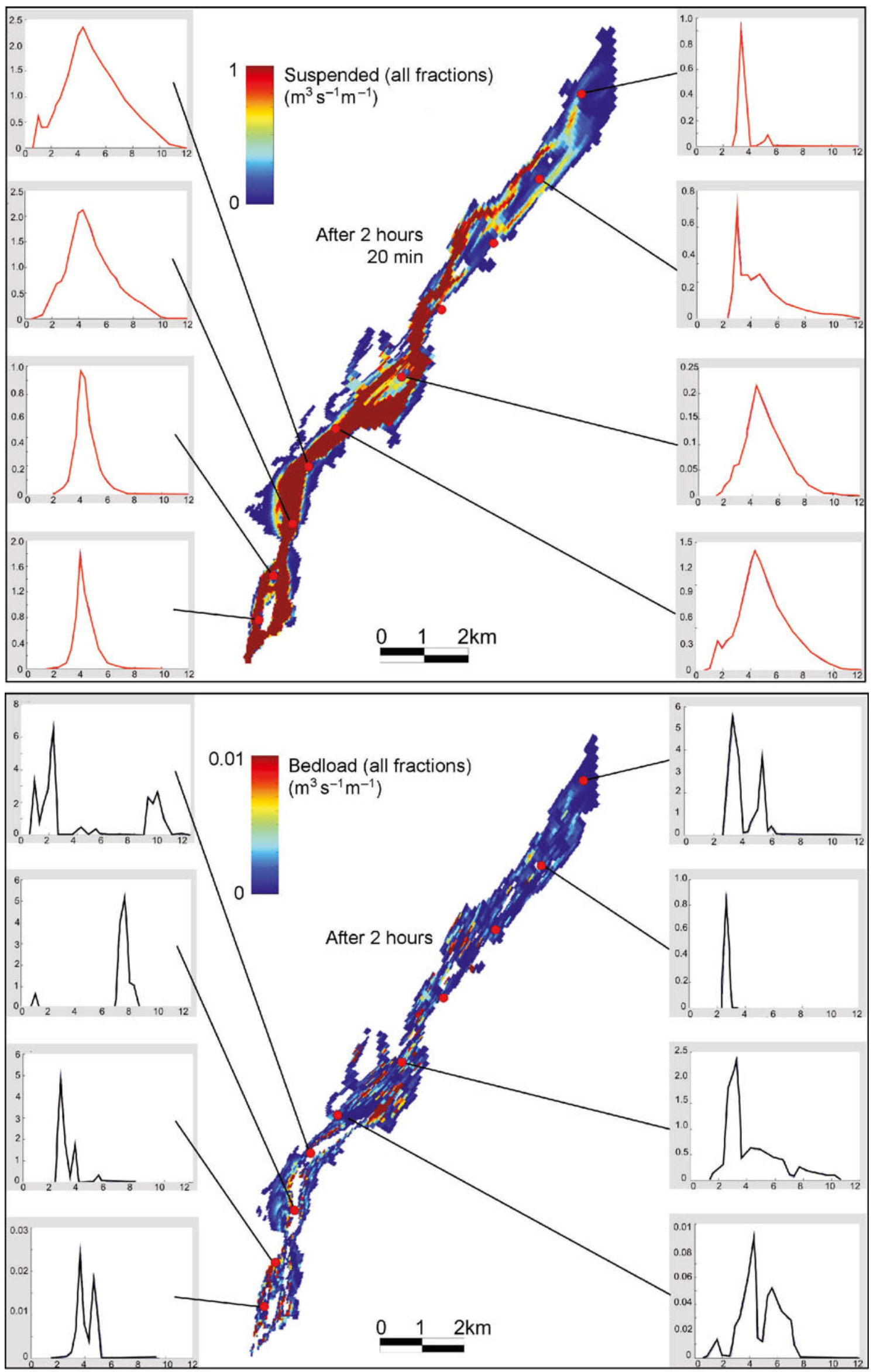

Fig. 7. Spatial and temporal variation in suspended load and bed load. The total of all sediment fractions is presented only. Note that suspended load persists in phase with the water hydrograph, but bed load is extremely transient and exhibits pulses. $x$ scale is time (hours) since flood initiation. Note $y$ scale $(\mathrm{m})$ varies between graphs. 


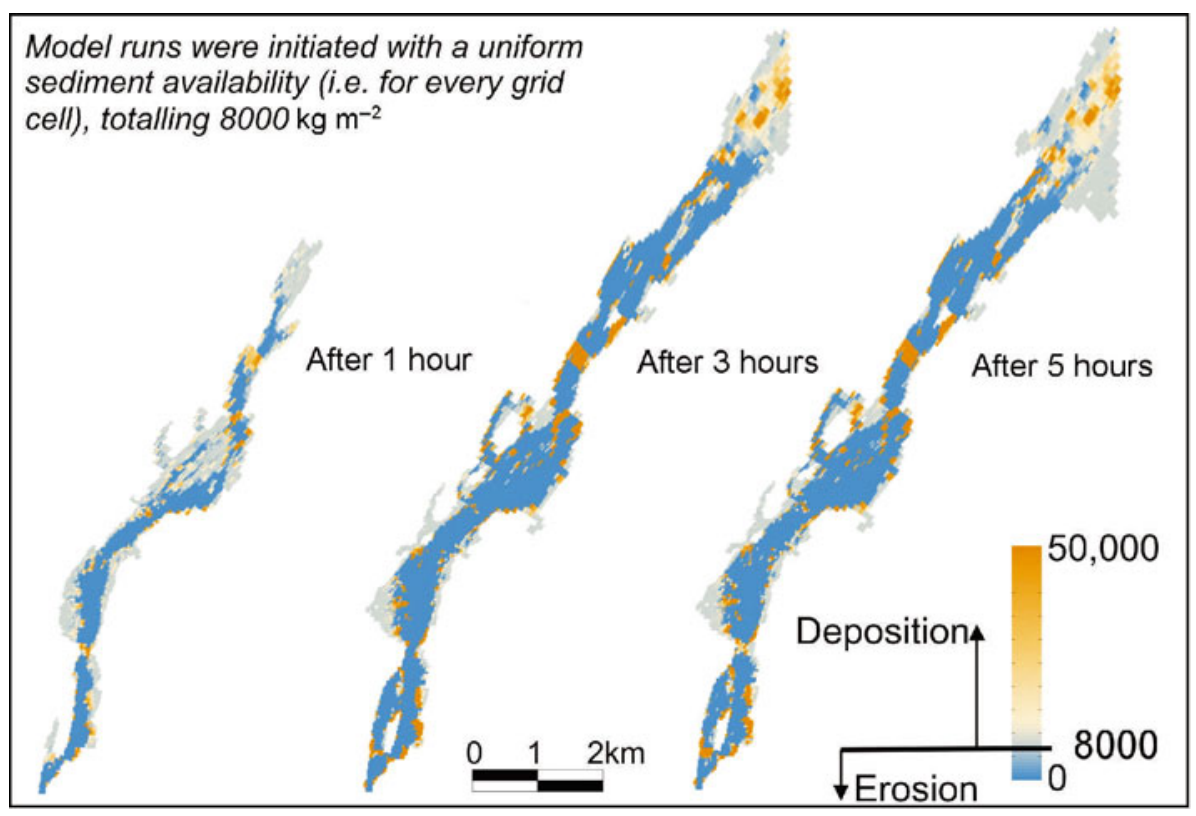

Fig. 8. Net gain and loss of pre-existing sediment, i.e. erosion and deposition, after 1, 3 and 5 hours. Each grid cell initially contained a total mass of $8000 \mathrm{~kg}$ of sediment of uniform depth.

(Fig. 9). Shear stresses of valley fill zones are low, with mean values ranging from $140-450 \mathrm{~N} \mathrm{~m}^{-2}$. The importance of whether reach-scale flow is accelerating or decelerating, as determined primarily by gradient in the absence of topographic widening or narrowing, is therefore again highlighted. Slackwater deposits are characterized by maximum flow depths $<8 \mathrm{~m}$ and maximum flow velocities of $<4 \mathrm{~m} \mathrm{~s}^{-1}$ (Fig. 9). However, mean flow depths and mean flow velocities in slackwater areas are $<2 \mathrm{~m}$ and $<2 \mathrm{~m} \mathrm{~s}^{-1}$ respectively. Thus, calculations of flow depths and flow velocities between different slackwater zones have a low standard deviation (1.25 and 0.5 respectively), illustrating relatively similar flow conditions at all locations. Mean shear stresses and mean stream powers within slackwater locations are less than $100 \mathrm{~N} \mathrm{~m}^{-2}$ and $4000 \mathrm{~W} \mathrm{~m}^{-2}$ respectively, although some values recorded are at least an order of magnitude greater (Fig. 9). Nonetheless, shear stress and stream powers within individual slackwater zones have a low range, implying spatially homogenous flow conditions at a particular site. Slackwater zones therefore have lowest flow depths, lowest flow velocities and lowest shear stresses and stream powers of any landform class (Fig. 9). Slackwater zones thus fall at the bottom of the proposed hierarchy.

\section{INTERPRETATION AND DISCUSSION}

This section will proceed through the same themes as above, i.e. firstly examining the spatial and temporal variation in hydraulics and sediment transport, and secondly discussing the association of modelled hydraulics with landforms and sediments.

\section{Spatial and temporal variation in jökulhlaup hydraulics and sediment transport}

The large difference between frontal flow velocity (Fig. 4) and main body velocity is attributed to the relative decrease of form roughness with increasing discharge and hence greater flow depths. Main body velocity became faster and at peak stage, highly varied, as characterized by frequent hydraulic jumps between subcritical and supercritical flow regimes (Fig. 6a). The transition between the two regimes would have been a zone of turbulence, high-pressure and potential for high-magnitude fluvial phenomena such as cavitation and plucking (Whipple and others, 2000). These zones have been attributed to the production of, for example, cataracts, gorges and bedrock steps (e.g. Carrivick and others, 2004a; Carrivick, 2005), but precise mechanisms and hydraulic parameters of bedrock erosion remain unquantified. Supercritical flow predominates in narrow, steep channels and subcritical flow in wide, shallow reaches (Fig. 6a). However, supercritical flow also persists at some channel margins and around islands (Fig. 6a). Supercritical flow zones at channel margins in Kverkfjallarani correspond to a gap between valley floor lava flows and valley walls (Carrivick and others, 2004a), and in all cases reflect localized flow acceleration.

Peak discharge through Kverkfjallarani apparently attenuated very rapidly, due to high channel roughness where Manning's $\mathrm{n} \sim 0.05-0.1 \mathrm{~m}^{1 / 3}$ (Carrivick and others, 2004b). High roughness is a result of flow depths of the order of the height of form elements, in this case 1-2 m. Longitudinal energy losses were also caused by recirculation of water in backwater areas. Some of these backwaters are marginal to the main channel, for example, within tributary valley mouths (Fig. 6b), but others are caused by temporary hydraulic ponding upslope of topographic constrictions between mid-valley islands. Mid-valley islands thus caused flow acceleration, which would exacerbate streamlining processes and lateral variations in erosional capability.

Main channel flows remain relatively stable, despite rising stage, because backwaters accommodate water mass and thus help dissipate flow energy and to attenuate main channel discharge. Backwaters can also develop a surging flow, as flow laps over-bank in successive waves (Fig. 6d). Waves may also be produced from upstream ponding, as continued discharge periodically causes overtopping of shallow topography. Temporary hydraulic ponding in Kverkfjallarani could have been responsible for the deposition of 


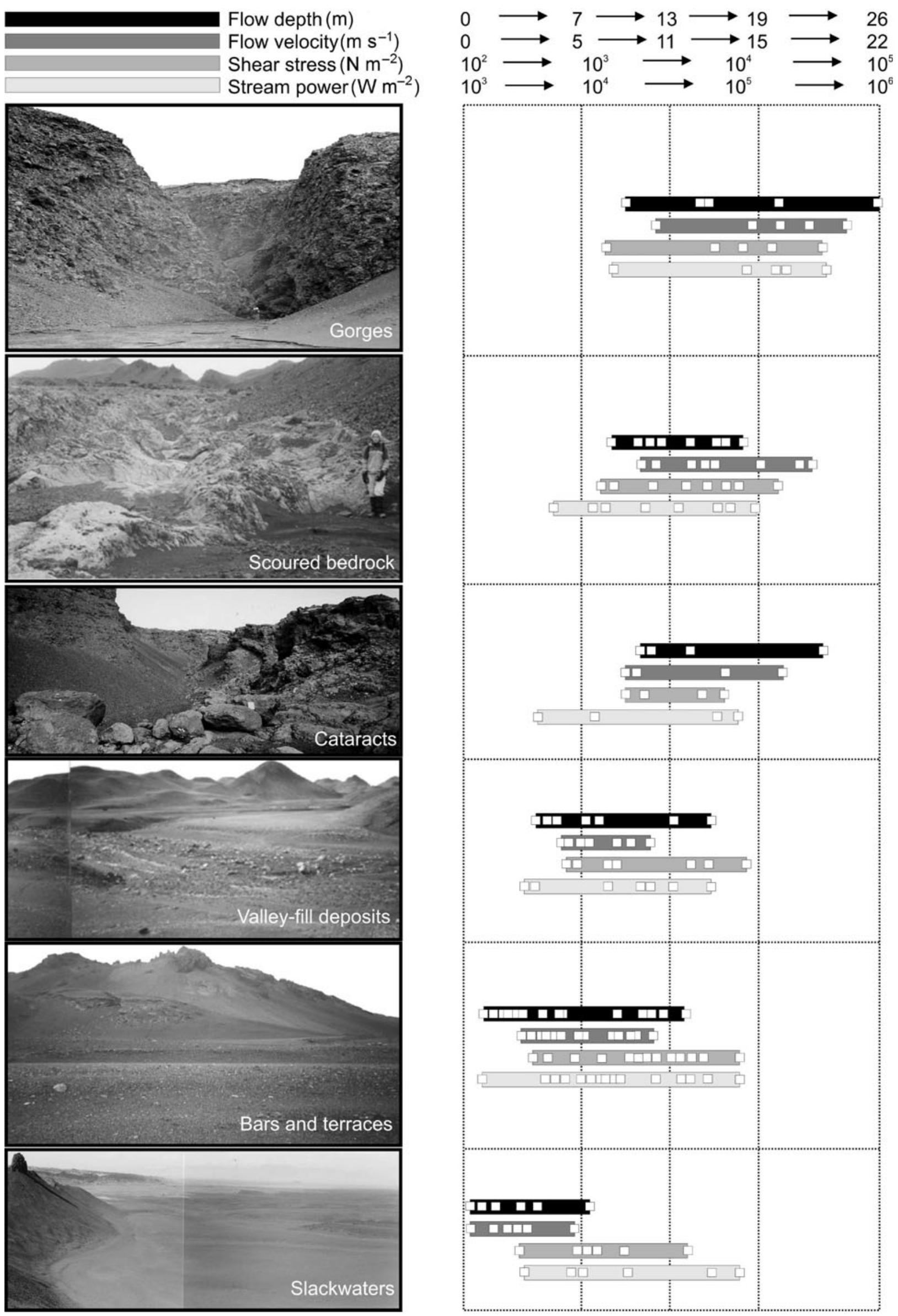

Fig. 9. Conceptual diagram illustrating a quantitative hierarchy of landforms based on a range of hydraulic conditions associated with each landform type. Landforms are arranged from those associated with deeper, faster and more powerful flows to those associated with shallower, slower and less energetic flows. The hierarchy is thus gorges, scoured bedrock, cataracts, valley-fill deposits, bars and terraces, and slackwaters. Data points and ranges are displayed for maximum values recorded in that landform area. 
valley-fill sediments (Carrivick and others, 2004a, b) and for longitudinal transitions between erosional and depositional zones (Carrivick, 2005). If ponding leaves palaeostage indicators (PSIs), flood reconstructions using PSIs could erroneously calculate flood hydraulics by assuming that those PSIs relate to channel flow. For example, boulder run-ups are common along Hraundalur (Carrivick and others, 2004b).

Suspended load comprised highly friable volcaniclastic material (Carrivick and others, 2004a, b), which is a feature shared by dilute lahars. This material is of relatively low density and therefore, for given clast sizes, becomes much more readily entrained than non-volcaniclastic material. Flows may thus approach hyperconcentrated rheology ( $\sim 20 \%$ sediment by volume), and suspended load transport persists over the entire hydrograph (Fig. 7). In contrast, bed load comprises 1-2 $\mathrm{m}$ basalt boulders plucked from subaerial lava, and hyaloclastite conglomerates (Carrivick and others, 2004b). Bed load therefore ensues only after a critical entrainment threshold has been reached, but also only where a suitable supply of sediment exists. Modelled bed load appears discontinuous, in pulses and is exhausted (Fig. 7) due to transient hydraulic conditions, as described above, but also because sediment was supply-limited, both in terms of volume and calibre.

Sedimentary character therefore exerts a strong control on the hydraulics of bedrock jökulhlaups, with feedbacks between sediment entrainment, flow density, flow hydraulics, particularly bed shear stress and thus capacity for erosion. The largest Hraundalur jökulhlaup was predominantly erosional (Fig. 8). Disparate deposition occurs marginally, in association with embayment and tributary mouths, laterally as bars and terraces and within the main channel in association with topographic islands and zones of hydraulically ponded water (Fig. 8). It is suggested that deposition could occur within a channel if flow velocity is decreasing, even if absolute velocity at a point within that channel section is sufficient for transport. Therefore it is rather important for landscape change to know if flow is accelerating or decelerating through a given reach, rather than just to calculate point measurements of flow velocity. It is an important output of this paper that the modelled net gains and losses of sediment (Fig. 8) closely resemble fieldmapped erosional and depositional landforms (Fig. 3), demonstrating the ability of this model to simulate rapid landscape change due to high-magnitude outburst floods.

Kverkfjöll jökulhlaups produce landforms and sediments analogous to those ascribed to the Missoula, Bonneville and Altai megafloods (Carrivick and others, 2004a, b, 2005). A comparison of the Hraundalur jökulhlaup hydraulics with those of the Missoula, Bonneville and Altai megafloods is given by Carrivick (2006) and therefore is not repeated here. Rather, this paper will compare modelled Hraundalur jökulhlaup hydraulics with mapped landforms and sediments in Hraundalur, Kverkfjallarani.

\section{Association of modelled hydraulics with field-mapped landforms and sediments}

Figure 9 illustrates that a wide range of flow conditions are experienced in areas of erosional landforms, specifically gorges, scoured bedrock and cataracts. This is suggested as erosional landforms are situated within a main channel and become inundated throughout the whole duration of an outburst flood. Therefore, both high and low stage flows inundate main channel and erosional zones, giving a far greater variability in all hydraulic parameters than depositional zones, specifically valley-fill areas, bars and terraces and slackwaters (Fig. 9). In contrast, areas marginal to a main channel such as bedrock alcoves and tributary valley mouths only become inundated at high stage and with relatively low flow depths. Flow velocities are also lower in marginal areas, being well aside from the thalweg. More complex analysis of hydraulic output is required to ascribe hydrograph stage to landform generation, but some indication can be given by the maximum values recorded for each landform type. Maximum values are 1-2 orders of magnitude greater for erosional landforms than depositional landforms (Fig. 9).

By describing a hierarchy of landforms, it is suggested that a landform evolution persists due to high-magnitude outburst floods with increasing flow erosion, and thus with increasing flow energy. The exact magnitude of this flow energy is dependant upon routeway geology. In Kverkfjallarani, landform evolution due to high-magnitude outburst floods is dominated by erosion (Fig. 8), i.e. with incision and relief exaggeration, the ultimate expression of which is gorges (Fig. 9). However, all of the eroded material must end up somewhere, and the apparent disproportionate areas of deposition imply that the majority of sediment is simply flushed out of the system, beyond the mouth of Hraundalur. This has important implications for sediment delivery during periods of deglaciation (when glacier instability and meltwater production are heightened, and volcanic activity is stimulated by rapid ice-unloading) to the north-central area of Iceland, and indeed to the north coast of Iceland.

\section{SUMMARY AND CONCLUSIONS}

This paper illustrates the advantages and new knowledge gained from coupled modelling of hydraulics and sediment transport in high-magnitude (fluid-flow) floods with high sediment content, such as jökulhlaups and dilute lahars. The example given demonstrates that a bedrock channelled subaerial jökulhlaup can be characterized by a highly varied flow regime. Jökulhlaup flow routing was dramatically controlled by topography, which caused channel avulsions and flow splitting around islands. Islands also caused hydraulic ponding as discharge rose more rapidly than could be transmitted downstream. Locally high and sustained peak water surface elevations are therefore observed. Topographic irregularity was partly responsible for downstream attenuation of peak discharge through high transmission losses as marginal flow inundated and backed up tributary valley mouths and recirculated within large embayments. Energy losses are also accounted for through sediment transport, which produced a largely erosional channel system. Model results suggest that suspended load transport occurred directly in phase with the discharge hydrograph, but that bed load transport was transient in space and time. Bed load transport was limited to the main channel, close to the thalweg and rapidly became limited by supply. Field observations not presented in this paper suggest that sediment to jökulhlaups from Kverkfjöll was also calibre limited (Carrivick and others, 2004b). It can be concluded that due to the distinct topographic, geological (sediment supply) control, these flow characteristics are typical of outburst floods that are volcanically triggered, route through 
steep volcanic terrain and contain high concentrations of volcaniclastic sediment.

Comparison of modelled hydrodynamics and fieldobserved landforms permits a hierarchy of landforms produced by high-magnitude outburst floods to be proposed. These range from those associated with highest energy zones (erosional gorges, scoured bedrock, cataracts and spillways) to depositional and lowest energy zones (valley-fills, bars and slackwater deposits). The thresholds above which bedrock fluvial erosion can occur in Kverkfjallarani are $\sim 3 \mathrm{~m}$ flow depth, $\sim 7 \mathrm{~m} \mathrm{~s}^{-1}$ flow velocity, $\sim 1 \times 10^{2} \mathrm{~N} \mathrm{~m}^{-2}$ shear stress and $3 \times 10^{2} \mathrm{~W} \mathrm{~m}^{-2}$ stream power. Fluvial deposition can occur in Kverkfjallarani below the thresholds of $\sim 8 \mathrm{~m}$ flow depth, $11 \mathrm{~m} \mathrm{~s}^{-1}$ flow velocity, $5 \times 10^{2} \mathrm{~N} \mathrm{~m}^{-2}$ shear stress and $3 \times 10^{3} \mathrm{~W} \mathrm{~m}^{-2}$ stream power. These conditions are likely to be determined in part by the highly brecciated and fissile nature of pillow lava, which thus becomes dislodged and transported relatively easily. Pillow lava therefore readily becomes incised to form deep gorges. In contrast, subaerial lava comprising massive basalt with large ( $>1 \mathrm{~m}$ ) spacing of vertical joints, is preferentially plucked to form steps and headcuts or cataracts as well as areally extensive scoured bedrock surface.

Finally, the model presented in this paper produced a distributed net change in sediment mass that closely resembled field-mapped zones of erosion and deposition. The method therefore has a clear capability to simulate rapid landscape change due to a high-magnitude outburst flood.

\section{ACKNOWLEDGEMENTS}

The Icelandic Research Council and the Nature Conservation Agency gave permission to undertake research in Iceland. Grants from the BGRG, IAS and QRA are acknowledged. WI Delft Hydraulics granted two years use of the SOBEK model for academic research. D. Twigg of Loughborough University produced the DEM. The Earthwatch Institute funded fieldwork during the summers of 20012003. Thank you to all of the 2001-2003 Earthwatch Team IV volunteers and to O. Lowe, H. Deeming and L. Rushmer for invaluable and excellent field assistance. Sira, Loftur, Edda and Elisabet made us very welcome at Sigurdarskali. A. Russell and F. Tweed are thanked for their continued advice. Reviews by V. Baker and J. O'Connor substantially improved this paper.

\section{REFERENCES}

Becket, J.A. 1934. Iceland adventure: the double traverse of Vatnajökull by the Cambridge expedition. London, H.F. and G. Witherby.

Benito, G. and J.E. O'Connor. 2003. Number and size of last-glacial Missoula floods in the Columbia River valley between Pasco basin, Washington and Portland, Oregon. GSA Bulletin, 115(5), 624-638.

Bursik, M. and J. Reid. 2004. Lahar in Glass Creek and Owens River during the Inyo eruption, Mono-Inyo Craters, California. J. Volcan. Geotherm. Res., 131(3-4), 321-331.

Canuti, P., N. Casagli, F. Catani and G. Falorni. 2002. Modelling of the Guagua Pichincha volcano (Ecuador) lahars. Phys. Chem. Earth $A / B / C, 27(36), 1587-1599$.

Capra, L., M.A. Poblete and R. Alvarado. 2004. The 1997 and 2001 lahars of Popocatépetl volcano (Central Mexico): textual and sedimentological constraints on their origin and hazards. J. Volcan. Geotherm. Res., 131(3-4), 351-369.
Carrivick, J.L. 2005. Characteristics and impacts of jökulhlaups (glacial outburst floods) from Kverkfjöll, Iceland. (PhD thesis, Keele University.)

Carrivick, J.L. 2006. Hydrodynamics and geomorphic work of jökulhlaups (glacial outburst floods) from Kverkfjöll volcano, Iceland. Hydrol. Process., 21(6), 725-740.

Carrivick, J.L. and D. Twigg. 2005. Jökulhlaup-influenced topography and geomorphology at Kverkfjöll, Iceland. J. Maps, 17-25.

Carrivick, J.L. and E.L. Rushmer. 2006. Understanding highmagnitude outburst floods. Geol. Today, 22(2), 60-65.

Carrivick, J.L., A.J. Russell and F.S. Tweed. 2004a. Geomorphological evidence for jökulhlaups from Kverkfjöll volcano, Iceland. Geomorphology, 63, 81-102.

Carrivick, J.L., A.J. Russell, F.S. Tweed and D. Twigg. 2004b. Palaeohydrology and sedimentology of jökulhlaups from Kverkfjöll, Iceland. Sediment. Geol., 172, 19-40.

Clague, J.J. and W.H. Mathews. 1973. The magnitude of jökulhlaups. J. Glaciol., 12(66), 501-504.

Clague, J.J. and S.G. Evans. 2000. A review of catastrophic drainage of moraine-dammed lakes in British Columbia. Quat. Sci. Rev., 19(17-18), 1763-1783.

Costa, J.E. 1988. Floods from dam failures. In Baker, V.R., R.C. Kochel and P.C. Patton, eds. Flood geomorphology. New York, etc., John Wiley and Sons, 439-463.

Costa, J.E. and R.L. Schuster. 1988. The formation and failure of natural dams. GSA Bulletin, 100(7), 1054-1068.

Cronin, S.J., K.A. Hodgson, V.E. Neall, A.S. Palmer and J.A. Lecointre. 1997. 1995 Ruapehu lahars in relation to the late Holocene lahars of Whangaehu River, New Zealand. New Zeal. J. Geol. Geophys., 40(4), 507-520.

Denlinger, R.P. and R.M. Iverson. 2001. Flow of variably fluidized granular masses across three-dimensional terrain: 2. Numerical predictions and experimental tests. J. Geophys. Res., 106(B1), 553-566.

Denlinger, R.P. and D.R.H.O'Connell. 2003. Two-dimensional flow constraints on catastrophic outflow of glacial Lake Missoula over three-dimesnional terrain. In: Ely, L.L., J.E. O'Connor and P.K.House, eds. Palaeoflood III, Hood River, Oregon.

Eskilsson, C., J.I. Árnason, and D. Rosbjerg. 2002. Simulation of the jökulhlaup on Skeiðarársandur Iceland, in November 1996 using MIKE 21 HD. IAHS Publ. 271 (Symposium at Reykjavík 2000 - The Extremes of the Extremes: Extraordinary Floods), $37-43$.

Fagents, S.A. and S.M. Baloga. 2005. Calculation of lahar transit times using digital elevation data. J. Volcan. Geotherm. Res., 139(1-2), 135-146.

Haeberli, W. 1983. Frequency and characteristics of glacier floods in the Swiss Alps. Ann. Glaciol., 4, 85-90.

Hannesson, P. 1953. lagttagelser over vulkanismen i Kverkfjallarani i Island-vulcanism in Kverkfjallarani, Iceland. Geogr. Tid., 68, 66-68.

Höskuldsson, A., R.S.J. Sparks and M.R. Carroll. 2006. Constraints on the dynamics of subglacial basalt eruptions from geological and geochemical observations at Kverkfjöll, NE-Iceland. Bull. Volcanol., 68(7-8), 689-701.

Iverson, R.M. and R.P. Denlinger. 2001. Flow of variably fluidized granular masses across three-dimensional terrain 1. Coulomb mixture theory. J. Geophys. Res., 106(BI), 537-552.

Iverson, R.M. and W. Vallance. 2001. New views of granular mass flows. Geology, 29(2), 115-118.

Iverson, R.M., S.P. Schilling and J.W. Vallance. 1998. Objective delineation of lahar-inundation hazard zones. GSA Bulletin, 110(8), 972-984.

Jakob, M., M. Bovis and M. Oden. 2005. The significance of channel recharge rates for estimating debris-flow magnitude and frequency. Earth Surf. Proc. Land., 30(6), 755-766.

Jóhannesson, H. and Sæmundsson, K. 1989. Geological map of Iceland, 1:1500000 bedrock geology. Reykjavík, Icelandic Museum of Natural History and Icelandic Geodetic Survey. 
Karhunen, R. 1988. Eruption mechanism and rheomorphism during the basaltic fissure eruption in Biskupsfell, Kverkfjoll, north-central Iceland. 8802. Reykjavik. Nordic Volcanological Institute.

Lavigne, F. and J-C. Thouret. 2003. Sediment transportation and deposition by rain-triggered lahars at Merapi Volcano, Central Java, Indonesia. Geomorphology, 49(1-2), 45-69.

Lliboutry, L., B.M. Arnao, A. Pautre and B. Schneider. 1977. Glaciological problems set by the control of dangerous lakes in Cordillera Blanca, Peru. I. Historical failures of morainic dams, their causes and prevention. J. Glaciol., 18(79), 239-254.

Maizels, J.K. 1993. Lithofacies variations within sandur deposits: the role of runoff regime, flow dynamics and sediment supply characteristics. Sediment. Geol., 85, 299-325.

Maizels, J.K. 1997. Jökulhlaup deposits in proglacial areas. Quat. Sci. Rev., 16(7), 793-819.

Maizels, J.K. and A.J. Russell. 1992. Quaternary perspectives on jökulhlaup prediction. Quat. Proc., 2, 133-153.

Major, J.J. 2000. Gravity-driven consolidation of granular slurries implications for debris-flow deposition and deposit characteristics. J. Sediment. Res. A, 70(1), 64-83.

Manville, V. and J.D.L. White. 2004. Incipient granular mass flows at the base of sediment-laden floods and the roles of flow competence and flow capacity in the deposition of stratified bouldery sands. Sediment. Geol., 155(1), 157-173.

Marcus, W.A. 1989. Lag-time routing of suspended sediment concentrations during unsteady flow. GSA Bulletin, 101, 644-651.

Marren, P.M. 2005. Magnitude and frequency in proglacial rivers: a geomorphological and sedimentological perspective. EarthSci. Rev., 70(3-4), 203-251.

Meyer-Peter, E. and R. Müller. 1948. Formulas for bed-load transport. IAHR48, Proceedings, 3rd IAHR Congress, Stockholm, Sweden, International Association for Hydraulic Research, 39-64.

O'Connor, J.E. 1993. Hydrology, hydraulics, and geomorphology of the Bonneville flood. GSA Special Paper. 274. Boulder, CO, Geological Society of America.
Rushmer, E.L. 2006. Sedimentological and geomorphological impacts of jökulhlaup (glacial outburst flood) in January 2002 at Kverkfjöll, northern Iceland. Geogr. Ann., 88A(1), 1-11.

Rushmer, E.L., A.J. Russell, F.S. Tweed, Ó. Knudsen, and P.M. Marren. 2002. The role of hydrograph shape in controlling glacier outburst flood (jökulhlaup) sedimentation: justification of field prototypes for flume modelling. IAHS Publ. 276 (The structure, function and management implications of fluvial sedimentary systems), 305-313.

Russell, A.J. and P.M. Marren. 1999. Proglacial fluvial sedimentary sequences in Greenland and Iceland: a case study from active proglacial environments subject to jökulhlaups. In Jones, A.P., M.E. Tucker and J.K. Hart, eds. The description and analysis of Quaternary stratigraphic field sections. London, Quaternary Research Association, 171-208.

Russell, A.J. and 6 others. 2006. Icelandic jökulhlaup impacts: implications for ice-sheet hydrology, sediment transfer and geomorphology. Geomorphology, 75(1-2), 33-64.

Scott, K.M., J.L. Macías, J.A. Naranjo, S. Rodriguez and J.P. McGeehin. 2001. Catastrophic debris flows transformed from landslides in volcanic terrains: mobility, hazard assessment and mitigation strategies. USGS Professional Review and reassessment of hazards owing to volcano-glacier interactions in Colombia Paper, 1630

Sleigh, P.A. and I.M. Goodwill. 2000. The St Venant equations. http://www.efm.leeds.ac.uk/CIVE/CIVE3400/stvenant.pdf.

Stevens, N.F., V. Manville and D.W. Herron. 2003. The sensitivity of a volcanic flow model to digital elevation model accuracy: experiments with digitised map contours and interferometric SAR at Ruapehu and Taranaki volcanoes, New Zealand. J. Volcan. Geotherm. Res., 119(1-4), 89-105.

Van Rijn, L.C. 1984. Sediment transport, part II: suspended load transport. ASCE J. Hydraul. Eng., 110(11), 1613-1641.

Whipple, K.X., G.S. Hancock and R.S. Anderson. 2000. River incision into bedrock: mechanics and relative efficacy of plucking, abrasion, and cavitation. GSA Bulletin, 112(3), 490-503. 